\title{
PENYULUHAN PERANAN PANGAN FUNGSIONAL DALAM MENGHADAPI PANDEMI COVID-19 DI GKI PAKUWON JAKARTA
}

\author{
Adolf Parhusip ${ }^{1}$, Nuri Arum Anugrahati ${ }^{1}$, Natania ${ }^{1}$, Melanie Cornelia ${ }^{1}$, Bryan Anders ${ }^{1}$ \\ ${ }^{1}$ Program Studi Teknologi Pangan, Universitas Pelita Harapan, Tangerang, Banten
}

Email: adolf.parhusip@uph.edu, nuri.anugrahati@uph.edu, natania.fti@uph.edu, melanie.cornelia@uph.edu

\begin{abstract}
Abstrak
Masyarakat mulai menyadari akan pentingnya fungsi makanan, bukan hanya sebagai kebutuhan nutrisi melainkan juga sebagai alat penunjang kesehatan maupun sebagai obat. Makanan yang memiliki fungsi tambahan ini dikenal sebagai makanan fungsional. Klaim fungsional dari bahan pangan juga sering dieksploitasi oleh produsen makanan tanpa didukung oleh bukti-bukti ilmiah. Berdasarkan hal tersebut, maka Program Studi Teknologi Pangan UPH mengadakan penyuluhan yang bertujuan untuk memperkenalkan pangan fungsional termasuk jenis-jenisnya dan cara pengolahan makanan yang aman dengan fokus di masa pandemi COVID-19 kepada jemaat GKI Pakuwon Jakarta. Metode kegiatan berupa penyuluhan yang dilakukan melalui webinar secara online pada tanggal 9 Juli 2020. Hasil kegiatan PkM adalah para peserta tertarik mengembangkan pangan fungsional terutama dalam usaha makanan yang selama ini sudah dijalankan. Sebanyak 64\% peserta menyatakan informasi yang diperoleh sangat berguna dalam kehidupan dan $67 \%$ peserta menyatakan bahwa media presentasi dan tanya jawab sangat bermanfaat. Oleh karena itu, dapat disimpulkan bahwa penyuluhan melalui webinar peranan pangan fungsional dalam kehidupan sehari-hari ini dapat menambah wawasan dan pengetahuan jemaat GKI Pakuwon Jakarta khususnya pada masa pandemi COVID-19 dan perlu ditindaklanjuti dengan topik lain yang informatif.
\end{abstract}

Kata Kunci : pangan fungsional, COVID-19, klaim kesehatan

PENDAHULUAN

Pandemi penyakit akibat virus corona (COVID-19) telah mengubah kehidupan banyak keluarga di seluruh dunia. Penutupan sekolah, serta pergerakan yang terbatas membuat orang tua harus menyeimbangkan kehidupan dengan berbagai peran di rumah selama hampir sepanjang hari seperti mengasuh anak, bekerja, dan menyelesaikan tugas-tugas lain. Keadaan bertambah berat karena sebagian orang memborong stok makanan, sementara sistem pasokan pangan terganggu. Akibatnya, beberapa jenis pangan mungkin menjadi langka. Bagi banyak orang, tantangan pangan bukan hanya seputar ketersediaan, tetapi juga kondisi finansial karena tidak sedikit masyarakat yang 
kehilangan pekerjaan dan pendapatan pada masa ini. Dalam situasi sulit ini, dapat dimengerti jika orang tua cenderung mengandalkan makanan siap saji atau makanan olahan sebagai pilihan cepat dan terjangkau. Padahal masih ada pilihan makanan sehat yang tidak kalah praktis dan murah untuk disajikan.

Selain COVID-19, peningkatan jumlah penderita aneka penyakit kronis yang berhubungan dengan makanan seperti diabetes dan penyakit jantung koroner, menyebabkan masyarakat mulai memiliki kesadaran akan pentingnya mengatur pola makanan [1]. Makanan tidak lagi sekedar pemenuh kebutuhan gizi saja, melainkan sudah mulai beralih fungsi, sebagai pengatur/penjaga kesehatan juga sebagai obat alternatif. Makanan yang memiliki fungsi lebih dari sekedar pemenuh nutrisi, dikategorikan dalam istilah pangan fungsional. Fungsi tambahan ini bisa didapatkan dari komponen asli yang tergantung didalam makanan tersebut, perubahan karakter fisiko kimia akibat adanya proses pengolahan, maupun penambahan bahan non makanan yang memiliki fungsi kesehatan kedalam bahan pangan yang alami [2] [1].

Kurangnya informasi tentang pangan fungsional pada jemaat GKI Pakuwon Jakarta juga melatarbelakangi kegiatan PkM kali ini. Jemaat di gereja tersebut masih terbatas mengakses informasi tentang pangan fungsional dan klaim kesehatan yang diberikan oleh produsen makanan. Produsen makanan sering menyampaikan klaim kesehatan yang tidak didukung oleh penelitian medis [2] [3]. Oleh karena itu Program Studi Teknologi Pangan UPH melakukan penyuluhan bertemakan "Penyuluhan Pangan Fungsional Dalam Menghadapi Pandemi COVID-19 Di GKI Pakuwon Jakarta" secara online. Penyuluhan ini dilakukan untuk memperkenalkan pangan fungsional, jenis-jenis pangan fungsional, dan membantu menghubungkan masyarakat awam khususnya jemaat GKI Pakuwon Jakarta mengenai klaim kesehatan dari aneka pangan fungsional berdasarkan hasil penelitian penelitian ilmiah.

\section{METODE}

1. Penyuluhan dalam bentuk webinar secara online dengan penjelasan dan presentasi mengenai pangan fungsional meliputi pengertian pangan fungsional beserta contoh-contoh hasil penelitian ilmiah yang mendukung klaim fungsional tersebut, jenisjenis sumber bahan lokal yang juga memiliki nilai fungsional, dan penerapan teknologi proses pengolahan yang dapat meningkatkan 
dan mempertahankan sifat fungsional dari bahan pangan.

2. Diskusi terbuka serta tanya jawab mengenai klaim-klaim pangan fungsional yang beredar di masyarakat.

3. Evaluasi terhadap pelaksanaan pengabdian masyarakat yang mencakup kesesuaian kegiatan pelatihan dengan kebutuhan jemaat GKI Pakuwon Jakarta dan sekitarnya, ketercapaian tujuan kegiatan pelatihan dengan masalah yang dihadapi jemaat GKI Pakuwon Jakarta dan sekitarnya (kompetensi penyuluh dan keberlanjutan program PkM), evaluasi secara berkala melalui komunikasi langsung dengan cara menjalin komunikasi via surat, email, telepon kepada Pengurus GKI Pakuwon Jakarta, webinar, dan seminar hasil PkM.

\section{HASIL DAN PEMBAHASAN}

Berdasarkan penyuluhan tersebut dapat di bahas:

\section{Pelaksanaan Webinar}

Pertemuan pertama dengan pihak GKI Pakuwon dilakukan pada bulan Mei 2020 mengingat pada saat perencanaan penyuluhan akan dilakukan SD Budi Mulia Bogor namun batal diadakan karena wabah COVID-19 sehingga semua kegiatan dihentikan dan dialihkan ke GKI Pakuwon dan kegiatan dilakukan secara online melalui webinar. Setelah komunikasi dilakukan dengan Ibu Yerusa selaku Pendeta GKI Pakuwon mengundang Program Studi Teknologi Pangan untuk melakukan penyuluhan peranan pangan fungsional dalam menghadapi COVID-19 ini bagi jemaat GKI Pakuwon Jakarta dan sekitarnya sehingga diharapkan jemaat dapat mengantisipasi, memilih dan memilah pangan sehat yang murah dan aman untuk dikonsumsi sebagai bentuk pertahanan diri karena kandungan komponen zat nutrisi yang mampu meningkatkan imunitas tubuh untuk melawan COVID-19. Tim PkM kemudian melakukan konfirmasi ulang mengenai topik penyuluhan, jumlah peserta serta susunan acara pelatihan. Kemudian Tim PkM membuat materi penyuluhan dan juga menyiapkan materi karena dilangsungkan secara online melalui platform Zoom. Tim PkM Program Studi Teknologi Pangan mempersiapkan seluruh perangkat untuk kegiatan webinar seperti poster untuk sosialisasi kepada jemaat yang berisi informasi tanggal pelaksanaan, registrasi peserta, link Zoom yang digunakan dan informasi gratis, dan narasumber dari Program Studi Teknologi Pangan Universitas Pelita Harapan.

Kegiatan PkM dilaksanakan pada hari Kamis/9 Juli 2020. Persiapan acara dimulai pukul 07.30 WIB dengan persiapan teknis 
peralatan webinar (sound, kamera, recording, sertifikat, publikasi, registrasi, kuesioner, host dan co-host). Acara pembukaan dimulai tepat pukul 10.00 WIB diawali dengan kata sambutan yang langsung disampaikan Ketua Program Studi Teknologi Pangan UPH oleh Bapak Ir. Wilbur Donald Pokatong, MSc., P.hD, dilanjutkan kata sambutan dari pihak GKI Pakuwon yang disampaikan oleh Ibu Pdt. Yerusa Maria Agustini, S.Si., M.Pd dan dilanjutkan dengan materi pokok webinar.

Kegiatan webinar ini dihadiri oleh 59 orang peserta, yang terbagi menjadi 2 bagian yaitu peserta yang mengikuti Zoom 26 orang, sedangkan yang mengikuti melalui Youtube 33 orang. Peserta tersebar dari jemaat GKI Pakuwon, GKI Pakis Raya, GKI Puri Indah, GKI Pamulang Indah, GKI Serpong, GKI Serua Indah dan GKI Singkawang Kalimantan Barat. Pada bagian pertama dari penyuluhan, diperkenalkan konsep definisi, jenis dan sumber pangan fungsional, kaitannya dengan pandemi COVID-19 serta imunitas tubuh dan hasil-hasil penelitian yang bersifat fungsional. Selanjutnya, pada bagian kedua diberikan pengenalan singkat mengenai pengertian pangan fungsional, serta contoh-contoh makanan fungsional yang diakhiri dengan tanya jawab. Selama penyuluhan, peserta aktif bertanya mengenai isu-isu tentang pangan fungsional yang dihadapi selama COVID-19 ini serta klaim klaim kesehatan dari berbagai media yang mereka terima. Acara tanya jawab berlangsung hangat karena banyak informasi, pengalaman, pengetahuan jemaat GKI Pakuwon Jakarta terhadap perkembangan pangan fungsional serta pemilihan bahan pangan yang aman dan bergizi tinggi.

\section{Peranan Pangan Fungsional}

Pada awal penjelasan webinar dengan menyamakan persepsi dan acuan dasar hukumnya diberikan penjelasan dan pengertian pangan fungsional menurut BPOM RI 2005 yaitu pangan fungsional merupakan pangan olahan yang mengandung satu atau lebih komponen fungsional yang berdasarkan kajian ilmiah mempunyai fungsi fisiologis tertentu, terbukti tidak membahayakan dan bermanfaat bagi kesehatan. Ruang lingkup materi yang disampaikan adalah pengertian virus corona, mekanisme masuknya virus serta mekanisme penangkal virus sebelum masuk tubuh dan sesudah dalam tubuh, dengan memanfaatkan makanan lokal yang ada di sekitar rumah seperti rempah kunyit, jahe, empon-empon, lengkuas dan buah-buahan hijau atau sayuran berwarna yang sudah dibuktikan secara ilmiah dan dipublikasikan di jurnal internasional. Semua informasi tersebut disampaikan dalam bentuk gambar-gambar dengan mengambil contoh 
konkrit dalam kehidupan sehari-hari untuk memudahkan pemahaman jemaat GKI Pakuwon Jakarta.

Selanjutnya dipaparkan pengertian tentang Keamanan Pangan menurut Peraturan Pemerintah Republik Indonesia Nomor 28 Tahun 2004 tentang keamanan, mutu, dan gizi pangan adalah kondisi dan upaya yang diperlukan untuk mencegah pangan dari kemungkinan cemaran biologis, kimia dan benda lain yang dapat mengganggu, merugikan, dan membahayakan kesehatan manusia. Ruang lingkup pengendalian keamanan pangan mencakup; pengendalian kebersihan (higiene sanitasi) pribadi atau penjamah makanan, pencegahan terjadinya kontaminasi silang terhadap makanan (baik yang berasal dari bahan makanan maupun tempat/peralatan yang dipakai). Selanjutnya pencegahan melalui pengolahan makanan yang baik (memasak pangan/memanaskan ulang makanan dengan tepat dapat membunuh mikroba patogen. Untuk mencegah terjadinya kasus-kasus keracunan seperti yg disampaikan banyak di medsos [5]. Pangan yang dimasak dengan suhu internal $70^{\circ} \mathrm{C}$ dapat memberi kepastian pangan aman untuk dikonsumsi), serta pencegahan melalui penyimpanan makanan pada suhu yang sesuai. Dengan menjaga suhu di bawah $5^{\circ} \mathrm{C}$ atau di atas $60^{\circ} \mathrm{C}$, pertumbuhan mikroba perusak akan lebih lambat atau terhenti.

\section{Evaluasi Webinar Peran Pangan} Fungsional Selama Pandemi COVID-19

Dari hasil kuesioner, dapat dilihat bahwa sebagian besar peserta $(78 \%)$ belum pernah mengikuti webinar perihal pangan fungsional dalam masa pandemi. Sebagian besar peserta juga (99\%) sangat tertarik mengikuti webinar ini karena merupakan pengetahuan praktis dalam menghadapi pandemi COVID-19 terutama dalam lingkungan keluarga dan gereja. Hal ini tercermin juga dari kecenderungan peserta (64\%) menyatakan informasi yang diperoleh sangat berguna dalam kehidupan. Sebagian besar dari peserta (67\%) menyatakan bahwa media presentasi dan tanya jawab yang dilakukan dalam webinar ini sangat memuaskan dan diperkuat dengan peserta $100 \%$ menyatakan PkM yang dilakukan sangat berguna sekali. Peserta juga sangat termotivasi untuk menerapkan dalam kehidupan sehari-hari sebagai bagian unsur sehat lahiriah dengan memilih konsumsi pangan fungsional yang sehat dan murah.

Sesi terakhir dalam webinar ini dengan tanya jawab tentang materi yang disampaikan. Pertanyaan yang disampaikan peserta cukup banyak dan beragam. Contohnya adalah 
pertanyaan tentang budidaya tanaman secara hidroponik. Hidroponik merupakan salah satu upaya keluarga untuk menanam tanaman yang bermanfaat bagi kesehatan dengan memanfaatkan pekarangan. Pada sesi ini terlihat jelas sekali peserta sangat antusias mengikuti tanya jawab dan mengungkapkan pengalaman sebagai informasi - informasi yang beredar di masyarakat mengenai makanan fungsional. Beberapa pertanyaan terkait teknologi pengolahan dan hubungannya dengan kesehatan juga disampaikan oleh peserta pada sesi tanya jawab. Tim PkM Program Studi Teknologi Pangan UPH memberikan souvenir kaos yang dicetak dan peralatan tulis untuk kelompok bina iman di GKI Pakuwon. Hasil kuesioner juga terungkap untuk perlu tetap diadakan webinar atau pelatihan hands on di komunitas GKI Pakuwon Jakarta dan disambut baik oleh Ibu Pendeta Yerusa. Adapun topik yang diharapkan dalam pertemuan berikutnya terkait dengan pemanfaatan kearifan lokal seperti berbahan dasar yang ada di sekitar mereka (mi singkong, saos singkong, daun kelor) yang diharapkan dapat meningkatkan ekonomi keluarga dengan memasarkan secara online termasuk kemasan yang digunakan.

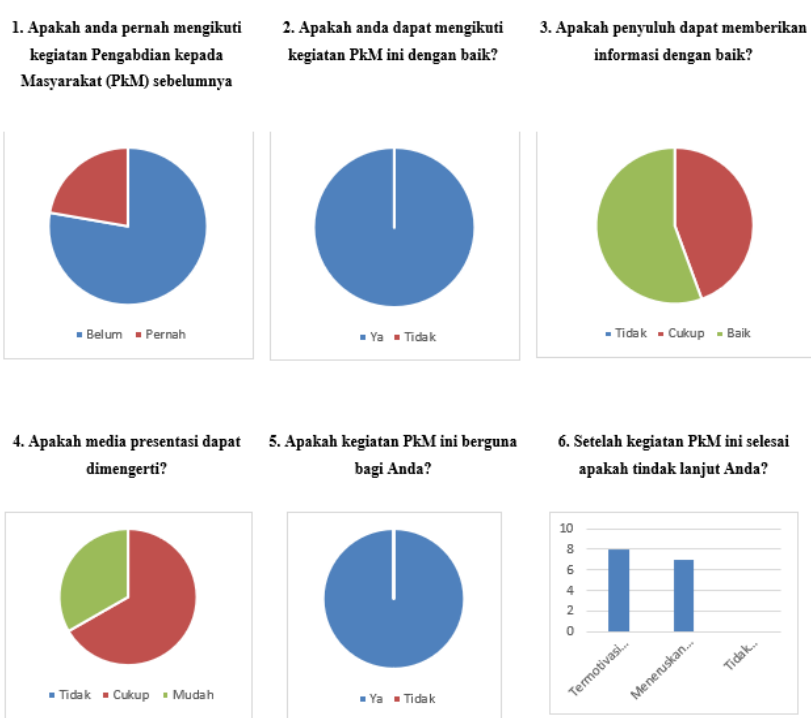

Gambar 1. Hasil Kuesioner webinar GKI Pakuwon

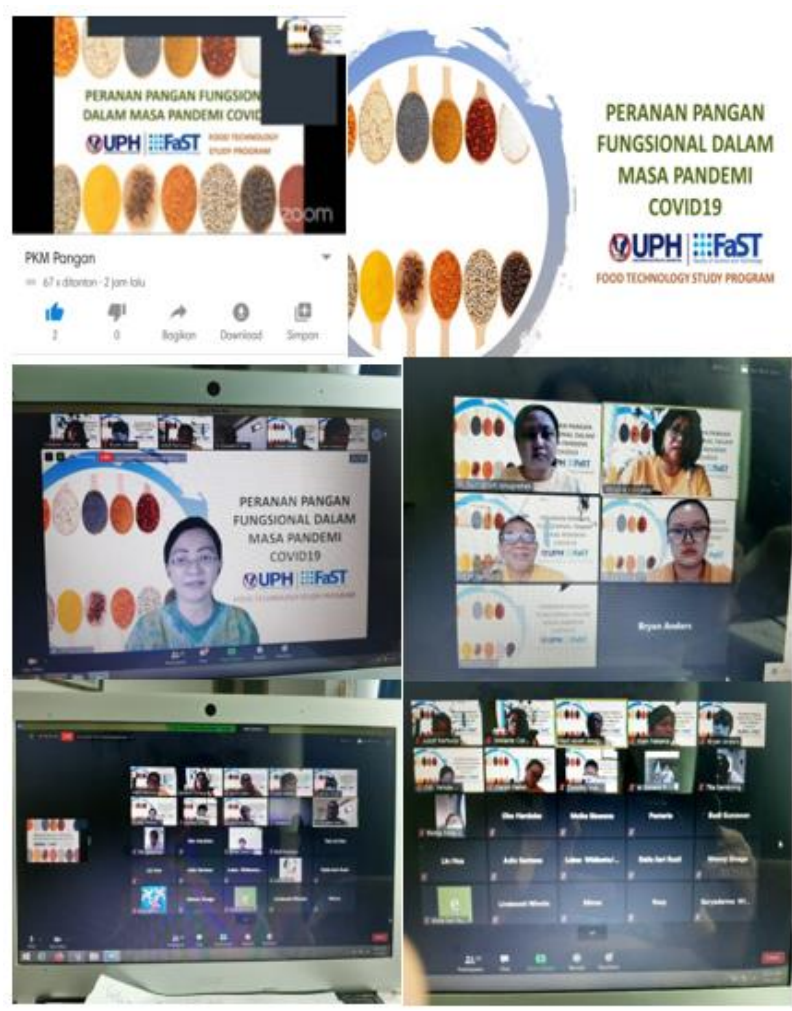

Gambar 2. Dokumentasi webinar dengan jemaat GKI Pakuwon Jakarta 


\section{KESIMPULAN}

Kegiatan webinar PkM yang berjudul "Penyuluhan Peranan Pangan Fungsional dalam menghadapi Pandemi COVID-19 di GKI Pakuwon Jakarta" telah dilaksanakan dengan baik dan interaktif berdasarkan banyaknya pertanyaan yang disampaikan oleh peserta dan antusiasme yang ditunjukkan oleh peserta selama kegiatan berlangsung. Penyuluhan secara online ini diikuti oleh 59 peserta dari lingkungan GKI Jakarta sekitarnya yang terdiri atas 26 peserta mengikuti melalui Zoom sedangkan 33 peserta mengikuti melalui Youtube. Kegiatan ini berlangsung dengan baik berkat kerjasama dari tim PkM yang meliputi dosen dan mahasiswa Program Studi Teknologi Pangan UPH serta didukung pihak dari GKI Pakuwon Jakarta.

\section{UCAPAN TERIMAKASIH:}

Ucapan terimakasih disampaikan kepada Ketua Program Studi Teknologi Pangan, Dekan Fakultas Sains dan Teknologi serta Lembaga
Penelitian dan Pengabdian kepada Masyarakat (LPPM) Universitas Pelita Harapan yang sudah membiayai PkM ini dengan No PM-004$\mathrm{FaST} / \mathrm{I} / 2020$.

\section{REFERENSI}

[1] Brown, A. (2011). Understanding Food: Principles and Preparation. $4^{\text {th }}$ edition. Wadsworth, Cengange Learning.

[2] Varzakas, T. and Tzia, C. 2016. Handbook of Food Processing: Food Safety, Quality, and Manufacturing Processes. CRC Press, Boca Raton.

[3] Surono, I.S., Sudibyo, A., dan Waspodo, P. 2019. Pengantar Keamanan Pangan untuk Industri Pangan. Deepublish, Yogyakarta.

[4] BPOM. 2019. Laporan Tahunan Badan POM. Badan Pengawasan Obat dan Makanan, Jakarta.

[5] Rahman, F.F. 2020. 34 Kasus Keracunan Pangan Terjadi di RI Sepanjang 2019. https://finance.detik.com, diakses tanggal 11 September 2020. 